\title{
Wired to Fail: Virtue and dysfunction in Baltimore's narrative
}

\section{Hugh Breakey}

Abstract: How can public institutions achieve their goals and best nurture virtue in their members? In this article, I seek answers to these questions in a perhaps unlikely place: the television series The Wire. Known for its unflinching realism, the crime drama narrates the intertwined lives of police, criminals, politicians, teachers and journalists in drug-plagued urban Baltimore. Yet even in the thick and quick of institutional dysfunction the drama portrays, human virtue springs forth and institutions (despite themselves) sometimes perform their roles. I begin this exploration of The Wire by drawing on Montesquieu and other political theorists to evaluate the problems facing state institutions-problems of diversity and principle as much as selfishness and power-mongering. I then turn to the prospects for virtue within modern institutions, developing and applying the system of Alasdair Maclntyre and paying particular attention to the role of narrative in cementing and integrating virtue.

\section{Introduction}

Screening over five seasons from 2002 to 2008 , the television crime drama The Wire explored the gritty side of contemporary Baltimore. In its opening season, the drama related the efforts of a cadre of police targeting a major crime family (the 'Barksdale's) entrenched in the lucrative local drug trade. An ensemble work, The Wire showed-cased both sides of the battle lines, from police superiors to new officers struggling to make stripes, from the top echelons of drug gangs to the school children carrying out street sales. An assortment of other characters filled out The Wire's dramatis personae: likeable drug addicts, despicable lawyers and family members of the police and the criminals. Capturing this broad swath of Baltimore's population, The Wire wove a complex tapestry, accreting new characters and events into the panorama as it progressed. Unlike most television crime dramas, there were no simple storylines. Developments in the police case occurred 
fitfully. Setbacks were routine. Unintended consequences and chance events littered the plot; longterm projects stumbled and collapsed, while offhand remarks and actions ramified to devastating effect. Even the end of the first season achieved little closure-arrests were made, but the Barksdale enterprise rolled on. In each of the following seasons, The Wire returned to the same police cohort in various forms, but the drama shifted focus: to the port workers; the local politicians; the education system; and finally the news media.

A long-term police reporter with the Baltimore Sun, David Simon, created the drama. Simon was also the primary writer for the show, along with collaborator Ed Burns-himself a Baltimore homicide detective for twenty years and then a teacher for seven in the city's troubled schools. The drama exudes the lived experience of both writers. Lauded by critics as some of the best television ever produced, the show warrants its description as 'unflinchingly realistic'.

This article explores issues of institutional governance and professional ethics as they emerge in The Wire. The idea that fiction can help us think about social and political arrangements is not new. Even if a work comprises pure fantasy, so long as we recognize its characters and situations as realistic, the fiction can help frame our moral imagination and political thought. For instance, William Golding's Lord of the Flies evoked the bloodthirsty anarchy lurking just outside civilization - the war of 'all against all' sketched earlier by the seventeenth century political theorist Thomas Hobbes. Fear of this lawless war and its horrors fuelled the dynamic of Hobbes' political theory, as people contractually acquiesced to a supreme sovereign -the 'Leviathan' (Hobbes, 1651/2008, p. 84). But the Leviathan could itself threaten human freedom more than the anarchy it superseded. George Orwell's 1984 portrayed how despotism rivals war in its horrors, capturing the fears animating John Locke, Montesquieu and other moderate, democratic political theorists of the modern era. David Simon and Ed Burn's The Wire presents us with another chapter in this oeuvre, narrating how constitutional, democratic bureaucracies governing capitalist, liberal milieus (the very institutions recommended by early modern theorists like Locke) carry their own human costs. 
But unlike Lord of the Flies and 1984, The Wire is not pure fantasy. While no characters or plot-lines take up real people and events (though some come close), the writer's intimate knowledge and comprehensive research into crime, drug-use, education, policing and bureaucracy in Baltimore explicitly informed the writing. Indeed, one of the driving purposes behind the show's creation was to tell these tales and empower the show's audience to understand the true complexity and depth of the problems assailing America's urban poor, a task that might once have fallen to journalists as much as dramatists (Simon, 2008). In The Wire these issues are brought to life as fiction, but a fiction rooted in lives lived and researched by the writers. Throughout I will refer to the institutions and characters in Baltimore-italicized so as to remind the reader of the fictitious nature of The Wire's setting. Baltimore is not real, it is not Baltimore-but its recognizable characters and situations, drawn from lived reality and close research, make it alarmingly lifelike nonetheless.

As well as its level of realism, The Wire is also a helpful resource for thinking through institutions and virtues because of its complexity. Academic treatises often specialize, looking through a single lens at multi-dimensional problems. Explaining why they teach The Wire, Harvard lecturers stress how the show captures the web of institutional inter-relations-economic, educational, criminological and ethical-that conspire to crush America's urban poor (Chaddha \& Wilson, 2010). This paper shadows this multidisciplinary aspect, bringing together lessons for institutional governance from political theory before turning to the cultivation of professional ethos and virtue. (Even so, I cannot cover everything. Economic decline, to take one thread I shall not pursue, contributes heavily to Baltimore's failings, depriving government institutions of desperately needed funds and sundering locals' prospects for legitimate employment.)

I begin our exploration in Section One recollecting some of the traditional reasons why we need institutions like Baltimore's-namely, they help prevent serious abuses of state power. In Section Two I then consider the flipside of such institutions; the way integrity measures can themselves impel problems and subvert the best of intentions (this being perhaps the major theme of The Wire). 
Section Three explores the main solution to these problems present in Baltimore-the professional ethic of a select group of police and other institutional actors. Baltimore's police refer to their ethic in a particular way: they praise an officer by saying, 'He's real police' or 'She's a natural police'. The first syllable is emphasized-police-and in what follows I will refer to the ethic in this way. Thus, 'police' are the officers populating the police department; 'police' refers to this special ethic and the small coterie of police officers who abide by it. I investigate this police ethos by applying Alasdair MacIntyre's work on virtue ethics, and I develop MacIntyre's account by filling out some of the ways these virtues relate to the available narratives - the stories told by institutional role-holders making sense of what they do and relating it to their larger life. I conclude by drawing together the two threads of institutional structure and virtuous ethos, arguing that even as they provide vital resourcing and oversight, institutions must learn how to stay out of the way of virtue.

\section{Problems impel institutions}

In a snapshot, The Wire narrates the story of a small coterie of (mostly) dedicated institutional agents being systematically punished for trying to do their job well. Making the show at once frustrating and perplexing, the lead characters are stymied not so much by evil villains, but by the very institutional processes and actors designed to facilitate and promote correct action. As Simon puts it in his audio commentary to episode three of Season Three, The Wire isn't cynical about human beings - but it's very cynical about contemporary institutions. For this reason, commentators routinely characterize The Wire as showcasing institutional dysfunction.

I follow this lead in employing the drama to highlight how mechanisms we might suppose empower institutional integrity in fact undermine it. But at the outset we have to be careful in making allegations of institutional dysfunction. I do not mean we should question the very idea of institutional dysfunction. For our purposes I assume we can speak sensibly about institutions having a 'function'. This function describes the purpose for which the institution was created, and 
constitutes the continuing public justification for it. When critics challenge the existence of the institution, questioning whether society should tolerate its social, political, or brute monetary costs, defenders of the institution justify it by marshalling the institution's function. So for police we might say the function is (something like) keeping the peace by arresting and building solid legal cases against those who commit criminal acts; for teachers it is to educate children to the point where they can function as adults and join the workforce; for journalists it is to faithfully relay relevant events to their audience, especially regarding political issues and governance; and so on. In each case, the function justifies the institutions, and we say the institution has 'integrity' when its structure and ethos ensure the institution reliably performs this function.

Now consider how we judge when an institution counts as dysfunctional. It will not do to simply assert that the institution fails in its function. Almost any institution fulfils its function to some extent and imposes various costs even as it succeeds. We would hardly gain from comparing Baltimore's institutions to some imagined utopia unpopulated by human beings as we know them to be. Equally, we would not learn anything by comparing Baltimore's institutions to other television dramas where every institutional actor, except in exceptional cases, diligently carries out their assigned role. The Wire differs from (say) Law and Order not insofar that Baltimore's institutions are dysfunctional, but that they are so realistic, filled with human beings that we all recognize from our own occupations (and, sometimes, our own mirrors).

As a consequence, I submit we deliver a comparative judgement when we speak of dysfunction. For an institution to be dysfunctional, it must be that we can locate other institutions that are actual options and could perform the role better. (Alternatively, in extreme cases we might decide that the function is not worth filling at all, given the costs-we will later return to this possibility in the context of the war on drugs). As Buchanan and Keohane stress in the international context, before we make a judgment about an institution's legitimacy, we should consider the realistically available alternatives to that institution (2006, p. 422). Despite grievous flaws, an institution yet may be the 
best option we possess for fulfilling a vital role. Winston Churchill once described democracy in such terms, extolling it as the worst system of government except all those other forms that have been tried from time to time.

What does this comparative point mean in concrete terms? This point forces us to reflect on the attractiveness of other options. Such reflection, I suggest, cautions us against setting the standard too high. Containing the signature defence of the 'separation of powers', Montesquieu's

(1748/1989) The Spirit of the Laws was destined to become one of the most influential treatises on institutional design and constitutionalism ever penned. Yet the Frenchman lambasts the capacity of human beings to build humane institutions. Despite men's love of liberty and hatred of violence, he laments, most people remain subject to despotic government $(1748 / 1989$, p. 63$)$. If Montesquieu is correct, then The Wire's unrelenting cynicism about institutions, combined with guarded optimism about human beings themselves, may prove a pervasive feature of our political reality. People may be decent enough, but we should not expect too much from their attempts to build humane institutions.

I want to stay with Montesquieu's separation of powers a moment longer, for it draws attention to issues that can slip too easily from our attention as we bemoan Baltimore's institutional problems. One of the key reasons for separating governmental powers between legislative, judicial and executive institutions (including police) is to make political persecution more difficult (Breakey, 2014). The separation requires coordination across different institutions and groups in order for political repression to occur-for example, a ruling faction in government arresting opposition figures. This requirement for coordination does not render persecution impossible, of course. Institutions may conspire-but the separation of powers at least forces conspiracy to occur. Even amid all the problems besetting Baltimore's institutions, there is little political persecution in any of the direct forms feared by (say) Montesquieu or Thomas Madison. Certainly, incumbent Mayor Royce illicitly strives for electoral advantage by shutting down services to the constituents of 
his challenger Councillor Tommy Carcetti, and manipulating the paychecks of the police and teachers to force their respective unions to endorse him. But direct persecution through criminal prosecution lies beyond the Mayor's political reach. The same follows for the police themselves. The Wire's second season surrounds the attempt by a vindictive police colonel, Major Valchek, to persecute a community rival, port union boss Frank Sabotka. But Valchek possesses only a limited capacity to do this, even given the considerable powers at his command. Initially his attempt consisted of no more than petty fines and time-wasting measures to inconvenience Sabotka and his workers. Valchek then shifted gear and set up a dedicated police squad to target Sabotka-but even here Valchek suspected Sabotka of actual criminal activity and the squad focused its attention on Sabotka's actual crimes. For all the alleged dysfunction therefore, at least some parts of the political machinery work as designed.

The problem of discerning what counts as a merit or flaw of an institution intertwines with the question of comparative judgement. From one standpoint, we might criticize any institution where a small-minded, spiteful character like Valchek can claw his way into a position of power (indeed, in the series' stinging closing montage, Valchek rises to the top position in Baltimore's police hierarchy). We might interrogate further, and question whether the institution was responsible for fostering his ugly character, or at least of failing to nurture his growth in a better ethical direction (Fagan, 2013, p. 18). Equally though, we might approach the issue from an opposite standpoint. If we suspect that no political institution can completely prevent men and women like Valchek forging their path to power, then we will do well to consider whether we would prefer him in an institution where his capacity for vindictive persecution is limited by the need for coordination with other rival institutions, as compared to the damage he could wreak as a monarch's general, or as a one-party state apparatchik in a Soviet-style bureaucracy. Appraised from that standpoint, Baltimore's fractious institutions might emerge as a surprisingly attractive option. 
Nor is this the only instance of Baltimore's institutions achieving their institutional purpose. While none of the institutional arrangements work seamlessly, Baltimore's institutions regularly solve problems: civilian councillors justifiably hound police officials about their job performancesometimes to significant effect; metrics used to evaluate police performance occasionally give vindictive superiors reason to bury their punishment of disruptive but proficient subordinates; and so on.

The result is we should be cautious about optimistic assessments of the capabilities of human-built and -staffed institutions, and acknowledge that sometimes Baltimore's institutions actually fulfil their mandate. But these two points hardly justify Baltimore's institutions. Even if these institutions help prevent the worst of anarchy and political persecution, it remains possible that the cure for such ills may be worse than the disease. It was on this general point that Locke rebuked Hobbes, arguing that Hobbes' drastic solution of a supreme sovereign was worse than the internecine violence the sovereign was supposed to banish. Locke countered that people guarding against interpersonal violence would be wary of opening themselves to despotism: "This is to think, that men are so foolish, that they take care to avoid what mischiefs may be done them by pole-cats, or foxes; but are content, nay, think it safety, to be devoured by lions" (1690/1947, p. II:93). In many places, we might countenance a certain amount of interpersonal criminal violence (foxes) in order to restrain the horrors of state violence (lions). But the grim state of Baltimore reminds us that the scales may not always tip in this direction. Residents of drug-torn Westside might well prefer the occasional rampages of a lion to the incessant attacks by foxes fomented by their socio-political environment.

To sum up: in taking a reforming eye to institutions we must take care not to throw the baby out with the bathwater. The institutional gap between the local executive (the Mayor's office) and the police department-and both of these from the judiciary-serves an array of important purposes, such as making political persecution more difficult. But this very point condemns us to having one 
institution (the executive) making judgments and decisions about the performance of another institution (the police department) about which it possesses little real knowledge and often quite different priorities. But the executive's efforts to make these judgements and decisions, as we will see, invite the use of metrics and devices that can frustrate the very action they aim to measure.

\section{Institutions impel problems}

\section{The problem of the unprincipled: selfishness}

Let's define an 'integrity system' as the entire complex of institutions and inter-relations serving to keep a given institution performing its function (Sampford, Smith, \& Brown, 2005). Why do we need integrity systems? A familiar answer responds that we need integrity systems because human beings tend to be selfish and power-hungry. This commonplace perhaps requires little defence. One of the ways institutions survive and achieve their goals is by funnelling power (authority, knowledge, resources, money, control over personnel) to certain role-holders within the institution (Sampford, 1988, pp. 194-196). Such power attracts the power-hungry, who so far as possible employ it to serve their own agendas. Even those who initially pursue institutional power for public-spirited reasons can fall into temptation once they hold that power in their hands - the rise of Councillor Tommy Carcetti exemplifies this tragic process in The Wire. Even an agent not selfish in the sense of grasping power and money may be afflicted by other more quotidian flaws: Baltimore overfills with the lazy, the alcoholic, the thuggish, the ambitious, the self-absorbed, the distracted, the contrary and the jaded.

In order to prevent the abuse (or just waste) of power, we can situate institutions into a larger complex-the 'integrity system' - constraining the institution's powers and inducing its members to accord with the institutional agenda. Unfortunately, the very reason driving our need for the integrity system (namely, humanity's selfishness) limits what we can expect from the integrity

system. If we need to hold Institution A accountable to Institution B because Institution A's members 
are, after all, only human, we must remember that this same point applies to the membership of Institution B. If power corrupts and attracts the already corrupt, then vesting Institution B with power over Institution A renders Institution B a potential problem itself. The Wire showcases this feature continually, with self-interested police officers monitoring self-interested criminals; the officers themselves accountable to self-interested superiors; who in turn find themselves judged by self-interested politicians. True, sometimes the system works. In some cases, politicians acknowledge self-interested reasons to fulfil the desires of the public for improved safety, and this impetus trickles through the bureaucratic layers to induce better policing. But just as often the selfinterest of the watchdog institution distorts the work of the watched institution in less helpful directions.

So much rehearses the commonplace query, 'Who watches the watchers?' But The Wire draws our attention to an even more straightforward point-though one easily missed. If Institution A needs to be accountable to Institution B because Institution A's personnel are, after all, only human, then we must expect Institution A's personnel to respond to the new accountability mechanisms with that same less-than-perfect spirit. The Wire delights in driving home this point. While Baltimore displays endless instances of institutions (schools, media, politicians) avoiding responsibility and distorting oversight mechanisms, its best example is found in the metrics measuring police performance. Each police homicide department (and each detective) has a 'clearance rate', tallying up how often they solve the murders assigned to them. The higher the clearance rate, the thinking goes, the more effective the detective or department. Unfortunately, some murders are much harder to solve than others, rendering the clearance rate a coarse-grained measure of police efficiency. Baltimore's police distinguish between 'dunkers' (murders that are easy to solve, usually performed by the victim's partner, ex-partner or family member) and 'stone cold whodunits' (the hardest murders to solve, such as anonymous victims shot dead on isolated street corners). 
Now it might be thought that, over time, differences on this scale will even out, making the metric useful in a rough and ready sense. However, this ignores the capacity of the police to 'game' the system - that is, to manipulate the environment to perform well on the metric without improving their actual performance. In this particular case, police can stage-manage the system by picking and choosing which murders they will investigate. The police realise that if they continually investigate easy cases and avoid the harder ones, then their clearance rate will shine. How can they avoid responsibility for harder cases? One way is to argue that a particular murder falls outside their jurisdiction -this occurs at the beginning of Season Two, when police uncover the grisly murder of twelve women who were entering the country illegally in a shipping container. For most of the ensuing season, opposing police units wrestle to avoid being left holding responsibility for working the case. On a different tack, police can report that the death was not a murder, even if evidence suggests the contrary. This happens with the immigrant women, and again later when a contract killer stages a jailhouse murder as a suicide. Our lead detective, Jimmy McNulty, uncovers the ruse, but his institutional fellows resist acting on his finding. As far as the other police are concerned, McNulty is perversely making work for everyone: doesn't his department already have enough murders to solve? The murder rests labelled as a suicide, its brutal perpetrator unpursued. Most chilling of all, when confronted with new evidence, the police can resist revisiting prior successful investigations-'successful' as measured by the 'clearance rate' metric. When Detective Bunk Moreland begins to suspect the dangerous but principled Omar Little is innocent of a murder charge, the detectives that initially built the murder case against him react angrily to Bunk's unwanted intrusions into their work. All this adds up to police detectives and departments actively avoiding conscientiously working a murder, not in spite of the accountability mechanism, but because of it. Far from facilitating the effective investigation of crimes, the accountability mechanism actually stymies investigation.

Even more troubling, what I have said so far applies to the simplest crime to evaluate externallymurder. Murder is easier than other crimes to evaluate because (as Major 'Bunny' Colvin) caustically 
observes, police departments cannot make bodies disappear. Crimes that do not lead to death or injuries demanding hospital treatment can be creatively re-categorized. In Season Three, with the stroke of a pen police chiefs downgrade serious crimes to petty ones; crime rates miraculously fall. Again, far from the accountability mechanism promoting effective police work, the device provides an institutional impetus for criminals to be accused of lesser crimes and given inappropriate sentences and records.

Now because the stakes here are so high, with innocents sent to jail and murderers walking free, we can easily feel appalled by the police officers' self-serving manipulation of these metrics. But we need to acknowledge that, from the perspective of the agent in question, the wrongdoing in such cases probably appears negligible and perhaps even necessary and justified. After all, the incentives the metric creates push the institutional actors in this direction-if they didn't perform in these ways, they may well have to surrender any possibility of promotion, and some would struggle to even survive in their current roles. Such agents will also see many others around them routinely playing the system to their advantage-and prospering because they do so. 'In a rigged game,' observes Ty Fagan (2013, p. 16) in his analysis of Baltimore's institutions, 'to play straight up is to invite exploitation'. Omar puts it more pithily again: 'Play or get played.' It would take a virtuous person indeed to stand fast to their principles in the face of the skewed incentives created by such metrics and their implementation.

The lesson here is that if we decide to impose accountability mechanisms because (some) institutional role-holders are selfish and power-hungry; we must ask: 'Given some of these institutional role-holders are selfish and power-hungry, how can we expect them to respond to these accountability mechanisms?' Usually, the answer will be: if these mechanisms can be manipulated to an agent's advantage, then they will be. 


\section{The problem of the principled: diversity}

The difficulty with designing effective integrity mechanisms is not limited to addressing the sort of selfish and power-hungry actors we might extract from the political writings of Hobbes, Machiavelli and other pessimistic political theorists. Most of The Wire's dramatis personae do not sink to such levels of callousness. Rather than being cardboard cut-out villains, Baltimore's characters just have their own agendas and values, and they engage with their institution as they pursue these. Even the values of The Wire's most principled characters fail to perfectly synchronize with their institutional mandates; quite simply, they have better things to do, their own lives to live. Each character understands his or her role differently, telling a different story of their life and the significance of the institution. Given the different places from which each person begins, their different agendas, and their different experiences with the institution, they each can hold different ideas about the nature of the institution and the purposes for which it is fit. The problem is, then, not merely one of Hobbesian foxes and Lockean lions-institutional design for humans requires herding cats.

Baltimore's skein of different perspectives tests the limits of leadership, coordination and accountability mechanisms. Institutions fail to achieve their purposes not because villains deliberately manipulate them for naked personal gain, but because each institution-member understands their role, and the institution itself, in different ways. This results in institutional failures created by the values and principles of the role-holders.

The Wire abounds with examples of this failure. In the third season, Major 'Bunny' Colvin attempts to lower crime in his district by turning a blind eye to drug dealing in specially designated 'free zones' (nick-named 'Hamsterdam' by the dealers). Colvin's desires are all principled ones. He wants to improve the safety of his community, to empower his subordinates with greater time to devote to more rewarding and effective police-work, and to leave his neighbourhood in a better state at the end of his policing career than when he entered it. Yet the plan involves systematically misleading the higher echelons of the police department about what he is doing-especially when the initiative 
begins to bear fruit and the crime rate drops. Some of Colvin's senior officers stay true to the plan out of loyalty to their commander-Lieutenant Carver even transports a murder crime scene away from one of Colvin's protected free-zones. In so doing, Carver protects his commander's precious experiment in crime-reduction by thwarting the efforts of the homicide detectives assigned to investigate the murder, who quickly unravel the ruse. In the end, Colvin's subordinates scuttle the plan because it does not accord with their views on the criminal-police relationship. Many of the rank and file police identify themselves at the front line of the war on drugs, battling the enemy, and they reject Colvin's attempts to broker a ceasefire. This storyline contains failures of institutional integrity at every juncture and at every level of command-and all of them fuelled not by selfishness but by each agent's deep-seated principles: Colvin's wish to improve his community; his aides' loyalty to their superior; and his subordinates' belief about their proper role.

Yet without question the most poignant case of values inducing corruption lies in the story of Frank Sabotka, related in the drama's second season. Sabotka is the union leader for the local Baltimore port workers'. But Baltimore's ports have fallen on hard times; key industries have collapsed and rival ports have improved, and the local port no longer draws the ships it did in its heyday. As a result, there is less work to go around for Sabotka's men-including his friends and his family. It is not just Sabotka's source of power and importance that is dying, however-neither is he anguished purely over the whittling away of this source of employment for his men. The waterfront community possesses its own culture and way of life, a shared history and interwoven relationships knitting it together as a supportive society. The collapse of the port threatens all of this: 'It breaks my heart,' he laments, 'that there's no future for the Sabotkas on the waterfront.' With the port's prospects worsening, Sabotka resorts to criminal activity. Needing to bribe key public officials (for instance to fulfil his dream of having the river dredged), Sabotka conspires in smuggling and stealing from the ships. When work injuries befall his members, and even when some cannot cope with the lack of regular paid work, Sabotka delves into his purse of ill-gotten gains to ease their tragedies. As his best laid plans collapse, and police and criminals threaten his freedom, his family and his very life, 
Sabotka realises his own tragedy: 'In my head, I thought I was wrong for the right reasons, you know?'

The lesson for institutional integrity here is that we must guard against the designs of good people no less than wicked people. An individual's personal conscientiousness does not guarantee they will contribute to the integrity of the institution.

Ironically, and in some rare good news, The Wire demonstrates that this same problem bedevilling institutional integrity equally confounds criminal operations. While perhaps not rising to the heights of Sabotka's values, genuine principles constrain many of Baltimore's criminals. Like the protagonists on the other side of the law, these principles betray striking diversity. This emerges vividly in the talk of 'the game'. Many of the gangsters invoke the game to explain and account for their actions, yet they all have violently (literally violently) opposing understandings of what the game involves, its purposes and its rules. For example, intensely loyal to his family, concerned with fairness to his fellows and his reputation on the street, Avon Barksdale valorises the 'game'. And Avon observes its principles even when they constrain him - he chastises 'Stringer' Bell when Bell ignores the 'Sunday truce' to seize an opportunity to kill an enemy. 'Sunday truce been around as long as the game,' Avon objects. But Avon's enjoyment of the game's gangster wars eventually imperils Stringer's calculated strategies for increasing their wealth, even as Stringer's violation of Avon's principles threatens to destroy Avon's reputation and connections on the street. The occasional collision of their values over the years becomes intolerable, and each ultimately betrays the other. Just as the diversity of human values creates problems for integrity systems, it creates points of tension and vulnerability in the operation of criminal enterprises.

\section{A solution: Ethos and virtue}

We have seen that the twin phenomena of diversity and selfishness pose serious problems for institutional integrity and the crafting of workable incentive structures. How can we solve (or at least 
mitigate) these difficulties? The Wire foregrounds one mechanism in particular: the professional ethos of each group. The plots involving the police continually showcase this feature, but it surfaces to some extent in Baltimore's media, politicians, teachers and dockworkers. In all of these cases we find role-holders inspired by their work within the institution, driven to pursue it as an end in itself. This professional ethic does not expunge human diversity nor overthrow selfishness, but it furnishes its devotees with a common perspective and language, and grants them an intrinsic reward for pursuing core institutional goals.

As I noted earlier, Baltimore's police invoke a special term for their professional ethic: 'police'. But what creates and sustains the police ethos? How can an institution capture and cultivate this most precious resource: actors who value the work for its own sake and act within their proper ambit because they desire to do so? In this section I explore the police through the lens of Alasdair Maclntyre's virtue theory.

\section{MacIntyre on virtue and narrative}

Maclntyre grounds his 'communitarian' theory of virtues in the Aristotelian idea of virtues as excellences of character. For Aristotle, these excellences apply to human beings as such: he enquired into the objective good life (the 'being-at-work') characteristic of humans, and then developed the virtues from this account (Aristotle, 2002; Sachs, 2002). Such excellences, however, also can be applied to specific professions and occupations. Indeed, Aristotle began his argument from the vivid cases of excellence in specific occupations, noting the distinctive work of the flute-player, sculptor and artisan before moving toward the characteristic being-at-work of the human being more generally (Aristotle, 2002, p. 1097b). In his landmark work, After Virtue, Maclntyre rejected Aristotle's account of an objective good for man, but preserved the core idea of virtue as excellences of character empowering a person to perform a specific role or activity.

Three key stages make up Maclntyre's 'general theory' (Beadle \& Moore, 2006, pp. 330-332; Schneewind, 1982, pp. 655-656). His theory begins with communities engaging in 'practices'- 
coherent, complex and cooperative activities with their own goals and rules (Maclntyre, 1981, pp. 175-179). These activities acquire their own standards of excellence as community-members striving to achieve the activity's challenging goals must behave in particular ways. Pursuit of these standards of excellence generates what MacIntyre calls 'internal goods' - newfound pleasures unique to the practice. Actors come to find fulfilment in the activity for its own sake, and not because of external rewards. But in pursuing excellence and seizing these internal goods, actors must behave (and think, feel and respond) in particular ways; they must adopt particular values, cultivate new relationships, and shift their perspective. In this way their characters develop virtues-virtues understood as evaluative judgments, modes of thinking and emotional dispositions enabling them to pursue excellence and the practice's internal goods. These virtues can then expand beyond the strict confines of the activity itself-the person begins to sense the good of a certain type of life, a vision that can provide an answer for the best kind of life the person can live (1981, pp. 177, 187). MacIntyre argues that every practice fuels at least some of the standard suite of virtues, including justice, courage and honesty. In order to enter the practice and achieve its goods, he says:

We have to learn to recognize what is due to whom; we have to be prepared to take whatever self-endangering risks are demanded along the way; and we have to listen carefully to what we are told about our own inadequacies and to reply with the same carefulness for the facts. In other words we have to accept as necessary components of any practice with internal goods and standards of excellence the virtues of justice, courage and honesty. (1981, p. 178)

MacIntyre illustrates his idea with the game of chess (1981, p. 176), but we can draw on an example from Baltimore. In a moving search for redemption, former violent criminal Dennis ('Cutty') Wise decides to open a gym to train local teenagers in boxing. One of his first and longest serving trainees is a young teenager, Justin. At first, Justin and his friends come along for their own reasons-to handle themselves better in street fights. Their interest in the art and discipline of boxing lies only in 
this external reward they hope to achieve. But over time, and as a trainee like Justin improves at the sport, he can come to appreciate boxing's internal goods-the sense of achievement, progression, power and enjoyment that can only be secured by boxing within the rules of its practice. Justin might come to thrill in the internal pleasure of being part of a great fight-even in losing a great fight-a consummation that he cannot access through other means of defeating his opponents. In this way the practice creates standards of excellence and internal pleasures that Justin can only seize by fostering changes to his judgments, perspective and emotional dispositions-by shifting his character in a virtuous direction. As he becomes further inculcated into the practice, Justin might find he cannot quarantine these personal changes to the boxing ring-the contagion of virtue spreads, and beings to infect his character itself.

Now this may all sound a little rosy, and I will shortly inject some qualifications. But to Baltimore's residents at least, the link between the training, internal goods and the possibility of virtue seems obvious enough. Everyone-police, religious leaders, politicians, nurses and most of all the mothers of the boys training-understands that Dennis' gym benefits the community and the young men training. To some extent, no doubt, this is because the boys' presence at the gym keeps them from selling drugs on the street. But the full depth of support Dennis receives across Baltimore's population suggests, I think, that they recognize the possibility of a deeper shift in the lives of the trainees, an increasing self-discipline and sense of pride in their achievements.

Even so, we can reasonably doubt whether the virtues of Justin's boxing practices will come to permeate his entire life (Schneewind, 1982, p. 656). The virtues of the gym need not spread to Justin's life as a whole-and even if they do, Justin might take part in other practices with countervailing virtues. If so, then virtues will not play their signature role of allowing their holder to achieve wellbeing across the course of his life (Maclntyre, 1981, p. 148). With this in mind, we progress to the second stage of MacIntyre's system, where he introduces the importance of narrative-of the stories people tell of their lives (1981, pp. 194-208). One answers the question of 
what one is to do, MacIntyre argues, by first answering the prior question: 'Of what story or stories do I find myself a part?' Seeing themselves as a character in a story empowers people to make sense of their own actions, to understand them as intelligible parts of the journey of their life. Maclntyre argues this narrative then encourages the spread of virtue into the life as a whole, by furnishing an archetype where the various practices (and their accompanying excellences) can be assimilated alongside one another in a recognizable way. Rather than just playing his role as a boxer engaged in a particular discrete activity, then, Justin might begin to think of himself as a character in a larger story (who trains and boxes sometimes) pushing him to integrate his boxing virtues with this larger role as a character in an over-arching narrative.

Now we need to reflect on what exactly is meant by 'narrative' in this context. A standard definition of 'narrative' reads: 'a spoken or written account of connected events; a story'. An ambiguity lurks here. Events can be connected without thereby creating anything worthy of a story. Arguably, a story is richer than a connected concatenation of events-story evokes features such as: a beginning, middle and end; character, transformation and growth; conflict and resolution; symbol and theme; plot, drama and tension; and so on. Story, we might say, is not just any connection, but connection of a special and deep kind. The literature on narrative ethics reflects this definitional ambiguity between dramatic stories and mere connection (Schneewind, 1982, pp. 658-659). On Maclntyre's telling, narrative evokes the depth of story, and his theory directly considers storytellers such as Jane Austen (Maclntyre, 1981, pp. 170-172, 222-126). So too, Maclntyre acknowledges the richness of story when he admits there are better and worse storytellers-some people learn to tell stories that grip us, others are bores (Maclntyre \& Dunne, 2002, pp. 9-10). When Maclntyre speaks of 'narrative' then, he invokes the richness of what we might call 'story-narrative'. However, later work on narrative ethics pares down this thick concept of story. In bulwarking the view that human beings inevitably consider their lives in narrative terms, theorists whittle down the concept to its barest bones, capturing little more than intentional actions consciously connected (or just reconciled) with one another (Rudd, 2007), perhaps augmented by a thin sense of 'beginning, middle and end' 
(Crowther, 2002). I term this impoverished but still connected conception, 'episodic-narrative'. The episodic-narrator's life-events remain connected via his memory and forethought-he is aware that one action in a practice or relationship today can impact on a separate event planned for tomorrow (compare (Rudd, 2007, pp. 69-70)). In comparison, the story-narrator seeks a greater intelligibility for her life, and she routinely converses, imagines and reflects upon her life as a whole. The more she does so, and imports lessons from these reflections into her life, the more she draws together the strands of her life together into a larger whole. She integrates the events in her life: through their thematic and symbolic unity; by their being driven by the agency of a stable and developing character; and, as stages (of inception, struggle and resolution) in a larger journey. As she employs these devices, the story-narrator unites the events of her life through the signature dramatic elements: theme, character and plot. In a nutshell, episodic-narratives connect events; storynarratives vivify them. This distinction between the two helps explain how every person cannot help but conceive their lives in narrative terms (episodic-narrative), but also how some people achieve a greater integration of their life through narrative (story-narrative).

Returning to Maclntyre's account, we can ask: How will the virtues of one practice incorporate into the larger lives of episodic-narrators versus story-narrators? For a person living an episodic-narrative life, we might expect at best some limited spread of virtues; emotional dispositions developed in one arena might unconsciously spread to others-or they might not. Clashes are possible between practices, after all, and what works in one context might not suit the episodic-narrator in another. A person journeying through a story-narrative, on the other hand, will display a greater integrity of character from one situation to the next. The story-narrator strives to create a particular and stable character, developing as she voyages through her life events. For this reason she deliberately exports her virtues from one context to the next and (allowing for context) incorporates the different virtues of her different practices together into a larger character. As we might express the result: the episodic-narrator has context-sensitive dispositions; the story-narrator possesses virtues. 
But will the tale the story-narrator's is trying to tell align with the other stories enacted by other characters in her community? The third stage of MacIntyre's system sees the virtuous agent's personal narrative fitting into the larger collective narrative. In this happy situation, the storynarrator succeeds in enacting her story because others around her are not collectively enacting stories that jar with her own. So too, the story-narrator will be able to picture her story as one part of a larger narrative, shared by others in her community and extending backwards into historical traditions and forward into the community to come. This larger tradition will not fully determine the narrative-the story-narrator guides her own journey—but it creates a crucial structuring device for that journey. On MacIntyre's telling, the story-narrator's writing of her own life story in concert with the stories of her community, and fuelled by her engagement in practices, empowers her to live the good life. However, while a person requires the full three stages to live a fully ethical, virtuous life, the world offers her no guarantee any of the stages will actually be available to her-as Baltimore demonstrates.

\section{Real police}

Let us now travel from the virtuous historical communities of Maclntyre's ethical theory to the dangerous streets of Baltimore. Over its five seasons, The Wire's core cadre of characters all exemplify the ethos of police: the seasoned detectives Jimmy McNulty, Bunk Moreland and Lester Freaman, the less-experienced Kima Greggs, and (to an extent) their supervisor: Colonel Cedric Daniels. They are not the only police in the drama-more peripheral characters such as 'Bunny' Colvin and Leander Sydnor share the virtues as well.

We can discern many of the features of Maclntyre's ethic in the police. Baltimore's police understand themselves engaged in a specific practice: namely, of keeping the peace by preventing, apprehending and bringing criminals to justice-especially violent and senior criminals. The police do so in a particular way: not as vigilantes, but within legal constraints. They want to make a 'case'. 
To count as a practice, this activity must give rise to internal goods and specific excellences. (Of course, the practice of policing also must produce results as well. After Virtue did not consider such 'productive practices', but Maclntyre later expanded his account to include them (1994, p. 194).) It turns out there are many required excellences: Police must be intelligent enough to outsmart criminals; perceptive to clues; inventive in approaches to uncovering crimes; and knowledgeable of the law. They need sophisticated social skills, especially in cultivating and exploiting confidential informants, and breaking criminals in interviews and interrogations. They need to work effectively in partnerships and investigative teams, and be patient, diligent and disciplined in their work.

When it comes to police, then, the standards of excellence in the tradition are high. Needless to say, few possess this combination of intellectual and character traits. Maclntyre implies in After Virtue that all those taking part in the practice can pursue the virtues appropriate to that practice. But Baltimore puts the lie to such egalitarianism. Police is an elite ethic. The challenging nature of the work means only a select cadre possess the necessary intelligence and mindset. Indeed, most of Baltimore's sworn officers cannot even see the ethos of police. Assigned to the same detail, young officers Herc and Carver are frustrated by Kima's sense of superiority. Formally, she does not outrank them. But instantly recognizable to her superiors as police, Kima takes part in strategic discussions, and thoughtlessly orders around Herc and Carver. This elitism tinges the police with a darker edge; the police can be neglectful of the contribution and work of those outside the ethic. This neglect comes to a head when Herc and Carver are left staking out a target's house long after the target has turned himself in to the rest of the team. Busy with breaking developments, none of the team's police spare a thought for the assignment set their two menial workers. At times the elitism stretches to outright scorn: McNulty crunches the numbers of the overall police population, whittling down the thousands of sworn officers to the small handful of police (most in the room listening to him) who venture out of the 'shallow end' and achieve genuine accomplishments. 
Not all those unable to attain these standards are blind to them, however. The tragedy of Officer Roland Pryzbylewski ('Prez') lies in his getting a taste of the joys of police-revelling in the meticulous and patient pursuit of master criminals through records, wiretaps and tracking devices. But the police force fires him after a series of incidents where Prez made disastrous spontaneous decisions, culminating in his fatal shooting of an undercover officer. "I'm not sure I was supposed to be a police," he laments to Freamon, his friend and mentor.

Do police evince the signature virtues Maclntyre related-of justice, courage and honesty? They do, at least in certain contexts. In accord with MacIntyre's understanding of justice, the police recognize desert when it is due. Kima, for example, is young, inexperienced, black, female and gay-any of which might prove a source of discrimination in the tough world of Baltimore. But the police recognize her potential swiftly, mentoring her and instinctively elevating her above her colleagues. The police display courage too, accepting great risks as they perform their roles. In Baltimore their own superiors and institutional processes threaten police more than the gun-barrels of violent criminals. Lester Freamon, for example, begins the drama having served fifteen years in a pointless desk job as punishment for pursuing a case 'the way it should be done'. Honesty-within the police clique at least-is also visible, especially for recognizing others' contributions and excellences. Genuine frankness also emerges in their disagreements. Framing their arguments within the police ethic, at times McNulty and Lester Freamon challenge each other; McNulty accuses Freamon of compromising the pursuit of the criminal kingpin Barksdale; Freamon counters that McNulty betrays the police ethic with his personal obsession with the criminal.

Turning to the question of internal goods, the practice swells with intrinsic rewards. The police revel in the thrill of the chase and the battle of wits as they pit their minds against the most cunning criminals. 'You have to admire it,' breathes Freamon, appreciating the lengths Barksdale's crew go to in avoiding wiretaps, 'The discipline of it.' They understand well the impact and social significance of what they (only they) can do. The police yearn for the moment of success when the handcuffs go on 
and the criminal realises he has been beaten and outsmarted. Their sense of their own excellence also emerges in their dim view of most other police-they enjoy the distinction of being police. All this adds up to a way of life and self-conception with its own meaning and intrinsic value. 'What am I?' asks McNulty, bereft when he is stripped of his rank and left without a case to work.

\section{The narratives of police}

I have argued that, evincing a range of excellences and internal goods, the activities of police count as a practice. But do the virtues of police extend into their lives and (all the more) into a life-welllived? The different characters of Baltimore's police in fact illustrate a range of diverse answers to this question, and to the role of reflection and narrative in improving true virtue.

Since there are three stages in Maclntyre's ethic, each of which may or may not take place, there are four possible alternatives. First, some police offers never enter the practice-never become police. For a character like Herc, policing is a mere means to the end of a paycheck or perhaps the accoutrements of a prestigious career. As the social scientists might express it, Herc's perceives his work as either a job or a career, rather than a 'calling' (Beadle \& Knight, 2012, pp. 442-443). Herc has not uncovered the internal goods of policing, nor attained the excellences required to succeed at policing's highest level. (Arguably, he lacks the intelligence, creativity and perceptiveness to do so, even if he altered his mindset regarding priorities, discipline and focus.)

Next there are those who engage in the practice, but without knitting the virtue of that practice into the larger concept of a life-well-lived: residing at Maclntyre's Stage One, they are episodic-narrators, not story-narrators. The Wire alerts us to two possible versions of this stage. First, a person might keep different practices in their life completely isolated. They fragment their life, effortlessly switching character as they turn from one role or context to the next. But there is another way a practice might be ill-fitted into a life, namely, when that practice becomes an over-riding priority, and swamps all other factors. In this case, far from benefiting one's larger life, the practices (and the effects on character it fuels) derail it. McNulty exemplifies this situation, though Bunk and Kima 
alsoreflect the ways the police life can scorch relationships and families. In a wrenching moment of realization, McNulty sunders himself from his calling as a detective: "The things that make me good at this job," he says, "make me wrong for everything else."

But how is this possible? How can the admirable excellences recounted above undermine the life as a whole, rather than ennoble it? Clearly, priority and effort make a difference. The more the intrinsic good of the pursuit mounts, the more the felt significance of the achievements builds, and the stronger the person's identification with being police, the less time, energy and commitment the police finds for his or her family and relationships. One's wider existence reduces to a life-support vessel for the practice. Social existence outside fraternizing with fellow police becomes fixed on quick, isolated thrills of intoxication or sexual infidelity. While we think of narrative as a device integrating life-as-a-whole, some of the stories told by Baltimore's police undercut this assumption. Rather, these stories recount characters and situations where the police succeed in their jobs but fail in their lives. In doing so, they risk crafting a character archetype that serves to justify and make intelligible this monomaniacal life. The stories and anecdotes McNulty and Kima swap serve only to fracture the links between home and work (complaining about partners not understanding the police life, giving advice on how the job can cover for infidelities). So too, the poignant eulogy and send-off given in Season Three to the fallen Detective Ray Cole reflects this fracturing. His personal failures interweave seamlessly into the story of his policing efforts. If this worrying thought is on the right track, then narratives can grant a sense of character and intelligibility to lives fractured and fragmented by the job.

But it is not all bad news. Lester Freamon shows that a police can integrate work and life. His character is stable and balanced, with no indications of a failing home life supporting his excellence in the job. In an intriguing parallel to the earlier discussion of episodic- and story-narrative, an exchange between Freamon and McNulty contrasts the episodic from the integrated life, ultimately fuelling McNulty's realization about the effects of the job on his life. Seeing him in at work on a 
Sunday, Freamon questions how McNulty thinks it will all end for him: 'The job will not save you, Jimmy.' McNulty rebuffs Freamon's charge, reflecting on the fulfilment of being in the midst of a good case. Cases end, he acknowledges, but another one always beckons. In the terms described above, McNulty perfectly expresses our Stage One: he revels in the internal goods of the practice, but the narrative he tells is episodic. He acknowledges the string of cases may not add up to anything, but so long as you are in the grip of an engaging case, he implies, you scarcely notice. From the integrated perspective of Stage Two and the story-narrative, Freamon shakes his head at the younger man: 'You know what life is Jimmy? It's the shit that happens while you're waiting for moments that never come.'

While Freamon possesses virtue and integrity, we might doubt whether any character in Baltimore attains Maclntyre's final stage, living in a shared community with a shared type of life, where each member tells intelligible and inter-woven stories, integrated with all the others in their community. To the contrary, Freamon's integrity seems so admirable precisely because it endures an institutional and social context so inimical to it. Maclntyre, perhaps, would pin this lack of shared community as a endemic feature of capitalism and modernity's institutional treasuring of external goods (money, power) over internal goods (Beadle \& Moore, 2006, pp. 329-330; Maclntyre, 1981, pp. 178-185, 245) - and The Wire's creators might agree in locating the problems in late-state capitalism and postmodern institutions (Simon, 2003). Certainly, large-scale bureaucracies struggle to understand and accommodate internal goods (a point to which we will shortly return). But another reason more specific to Baltimore also demands mention: the drug war. The effect of the war on drugs on the police force fuels Bunny Colvin's experiment of turning a blind eye to drugsellers in his 'free zones'. The worst thing about the drug war, the Major mourns, is that 'it ruined this job'. Some of this wreckage occurs because of the huge amount of resources required to stem the sale of the drugs, distracting police from more traditional and rewarding police-work. But another factor resides in the mentality of the drug war. Warring is not policing, Colvin observes. Good policing requires having a strong relationship with the policed community. But the us-and-them nature of the war, pitting 
police against all those who use or peddle the drugs, or receive money from the trade, or have family who do, threatens to sunder this link with the community. One reason Baltimore offers little prospect for fully integrated narratives, then, is that police and community tell their stories from different sides of the trenches. Still, the divide can be crossed; the informant and struggling drug addict Bubbles forges genuine relationships with Kima and McNulty; Detective Bunk Moreland morally challenges, and is challenged by, the principled gangster Omar Little; and Bunny Colvin himself reaches out to the convicted killer 'Wey-Bey', speaking to him soldier-to-solider, as it were, albeit ones caught on opposing sides.

\section{Ethos and institution}

The reader might feel scandalized by Major Colvin's reasons for decriminalizing the local drug trade-rethinking drug enforcement to make policework more rewarding might appear to Baltimore's urban poor an extraordinary mistaking of the real priorities. But there remains a vital feature of police I have not yet mentioned: the efficacy of the ethos. At least in The Wire's Baltimore, very little substantive police-work is achieved without the police. Ordinary police are simply incapable of the type of demanding work required to impact on the source of criminal problems, as opposed to their mere symptoms. Certainly, they can perform straightforward, formulaic work. The ordinary police keep in check the more overt criminality of the teenager drugsellers working the obvious corners. They succeed in solving the easier cases, and they play a serviceable role in plans orchestrated by the police. But beyond these limits, ordinary police simply do not have the capacity, patience or will to impact on the real sources of violence and fear. They stay in the 'shallow end'but Baltimore's real sharks swim in the deep.

Now I would not want to overplay the actual impact made by the police. Even when the police successfully build cases against notorious murderers, the next aspiring drug-lord simply steps into the breach. Demand for drugs drives their supply, new kingpin Marlo Stanfield replaces the jailed Avon Barksdale, and the game rolls on relentlessly. But even accepting this grim truth, effective 
police work does have an impact, at least in occasionally removing the most violent gangsters from the streets, and encouraging the major players to prudentially limit the violence they wreak on ordinary civilians. (Those who doubt the significance of these efforts might compare Baltimore with, say, current-day Buenaventura in Columbia, where criminal groups operate with almost total impunity (Human Rights Watch, 2014).)

So, if we accept that some police-work does have an impact, we might wonder why the ordinary police struggle to contribute. Some of the answer is simply a question of intelligence, creativity and perception: even if ordinary police were perfectly motivated, they do not possess the capacity to outthink the most sophisticated criminals (and colluding defence lawyers). But at least some of the inadequacy is explained by the skewed incentive structures and the difficulty of ensuring accountability related earlier. Police work carries myriad opportunities for the abuse of power; as well, external bodies struggle to appraise the effectiveness of the work performed. As we saw in Section Two, the same selfishness and diversity that renders oversight and metrics necessary means such mechanisms will be manipulated and distorted. Ordinary police tend to exert themselves to dodge the accountability spotlight-but that is not at all the same thing as putting effort into doing their job well. In contrast, police accomplish so much because their energies focus on doing the job right (and hence of acquiring the internal goods and excellences available in doing so).

If this is right, then it implies that cultivating the ethos of a practice is vital when we are faced with an institutional context where: we require excellence to overcome the intrinsic challenges of the work; we struggle to ensure external oversight and measurement; and, we perceive wide potential for the abuse of power. For the most utilitarian of reasons, then, we need to worry about whether police jobs are good jobs-not in the sense of being easy or stress-free, but in the sense of there being space for engaging in the practice of police and cultivating its ethos. Faced with the challenges presented by Baltimore's criminal class, it turns out that caring about productive output requires prioritizing internal goods. Institutional authorities must ensure the work is rewarding not out of a 
concern for the objective good life and its just distribution (Beadle \& Knight, 2012), but rather out of the desperate need to achieve the institutional task.

Lest all this sound too sanguine, the ethos of police possesses a darker side that threatens institutional integrity: police in Baltimore deceive and subvert institutions. This deceit emerges when police become frustrated with what they perceive to be inadequate resourcing. Doing the job the way it should be done' requires a certain minimum of time (sometimes overtime), personnel and material equipment, including money for confidential informants and protecting witnesses as well as technological devices for tracking and wiretapping. For the most part, the police avoid being grasping and unrealistic about what they need, but when resourcing drops below a certain threshold doing the job properly becomes impossible. In The Wire's final season, financial pressures force officers to work overtime for only a promise of eventual pay. In response, McNulty and Freamon pry open the funding faucet by fabricating evidence for a serial killer. The idea of such a predator seizes the public imagination and the money flows.

Another institutional threat posed by the police arises from their unyielding brittleness. Institutional priorities shift as executives respond to the pressures of the moment, often driven by the fickle attentions of the electorate, and sometimes by the personal desires of superiors. These shifts impact upon the police department and related institutions, including the judiciary and federal agencies. But the ethos of police sets its own goals and its own goods, and these do not yield to external pressures. Scorning other institutions that bend to the political mandates of the moment (such as the $\mathrm{FBI}$ and its post-9/11 obsession with terrorism), the police subvert attempts by their superiors to reassign roles and tasks against the grain of the police ethos. Curiously, this situation parallels Montesquieu's eighteenth century analysis of the use of honour by kings and despots. 'Honor,' the Frenchman observed, 'has its laws and rules and is incapable of yielding, as it depends on its own caprice and not on that of another.' (Montesquieu, 1748/1989, p. 27). A monarch can make use of this valuable moral spring, but must never request his nobles to transgress its dictates. The despot, 
however, must eschew all appeal to honor, as honor's demands will not yield to the despot's caprice.

What is the lesson in all this? I submit the lesson is the very one Montesquieu tried to teach the monarchy (specifically, the French monarchy to which he belonged). The monarchy hinges on honor as its fundamental principle, Montesquieu argued, depending on it as the moral lifeblood driving authorities to perform their institutional roles. But this principle shows why a monarch cannot wield absolute power without undermining his own standing (Montesquieu, 1748/1989, pp. 21-30). Suppose the King forces the authorities (the nobles) to act on his caprice and against the dictates of honor. Two possible results present. The nobles might spurn honor and submit to the King's caprice; but with the demise of honor the King (now strictly speaking a despot) can henceforth trust only in the precarious power of fear. Alternatively, the nobles might scorn the King's caprice; in this case honor is upheld but the King is compromised. From the courts of French nobility to the backstreets of Baltimore, I submit the lesson remains the same. The ethos of police helps Baltimore endure. Asking police to bend to the priorities of the moment, or failing to provide them with the minimal tools necessary to perform their tasks the way they should be done, can have only two outcomes. The ethos of the police may yield and so fracture-and everything must be thenceforth trusted to fear of external accountability measures. Or the ethos stands firm, and the police subvert the attempts to distort their activity to the instrumental needs of the moment.

What does this mean in concrete terms? I don't suggest that the police department should aim to systematically cultivate the police ethos. While in some contexts institutions might aspire to this virtue-promoting goal (Moore \& Beadle, 2006), realistically Baltimore's police department's powermongers would successfully manipulate and undermine any such attempts. However, it is not naïve to think the institution could undertake measures to prevent its most egregious clashes with the ethos. From a narrow instrumental perspective, a police commissioner might suppose that when circumstances dictate he can apply whatever resources he has to investigate a crime, assign 
whatever case-priorities to police work he wishes, request compromises in how police present their cases, and transfer officers from one case to another. But if he issues such orders without sensitivity to the ethos, these dictates can force police to choose between obeying their superiors, and respecting and pursuing the ethos of the police. Of course I do not mean no infractions on the ethos can be tolerated, but that Baltimore's institutions would do well to at least recognize the ethos and factor its importance into the decisions that are made. This is so even for the most brutally Machiavellian of the police hierarchy. When push comes to shove, superiors sometimes need to show real results-as the increasing desperation of the police hierarchy reveals in The Wire's third season, as the leaders squirm under the spotlight of public opinion and the Mayor's office. In the weekly administrative 'COMSTAT' meetings the Police Commissioner and Deputy Ops harangue and demote their subordinates, flailing about with no understanding of who really can solve crimes and why they do so. Taking any resistance to their orders as intolerable insubordination, Baltimore's police command have undermined and removed the very police who could get real results-just as a French monarch whose caprice undermined honour wonders why he must now rely on fear and punishment to have the most basic institutional tasks performed. The lesson is that an enlightened concern for institutional outcomes forces us to pay heed to the internal life of those in the institution. If we need an institution to perform a job well, we must avoid stifling and subverting the ethical practices that alone can achieve that level of performance.

In a similar spirit, we must return to the spectre of Baltimore's war on drugs. Imagine Major Colvin's instinct was right: the war on drugs ruined the job by chewing up massive resources in time and money, creating soldiers instead of police, and severing the link between police and community. All these factors undermine the capacity and drive of police to become police. Even if we were winning the war on drugs, conducting that war threatens the ethos of the police-and with it arguably the most precious crime-fighting resource we possess. 


\section{Conclusion: The Wire as narrative}

I began by arguing we have good reasons to structure institutions as we do; those reasons do not disappear merely because we encounter other problems (such as those expounded in The Wire). I then observed that even as the selfishness and diversity of humans impels us to create integrity systems governing institutions, these very features of humanity limit how effective we can expect such systems to be. External oversight will be stymied; metrics will be manipulated and mis-directed. In the final section I considered a device that promised to ensure institutional actors would value intrinsically the activities that fulfilled the institution's function: their professional ethos. The Wire's core example of this ethos was the police, and I discussed how narratives and institutions could work to support, but also to subvert, the virtues of this Maclntyrean practice. I suggested our scepticism about institution-building might make us resist believing integrity systems can cultivate such virtuebut I argued a more modest goal of keeping institutions out of the way of role-holder's pursuit of virtue may prove manageable and desirable.

In closing, we have seen the way narratives can bolster virtuous action and integrate practices into a life-well-lived. But as well as containing narratives about the police in the stories McNulty, Kima and Lester tell themselves, The Wire itself constitutes a narrative-and an instructive one at that. Arguably, The Wire offers a realistic model of what human narratives in the modern world must look like-a question of utmost importance if what was said above about practices, virtues, narratives and human happiness was on the right track. Like our own narratives, The Wire's are not pat, easy storylines, with issues raised and resolved within a discrete timeframe. As David Simon explains, 'The show is crafted as a visual novel; most of episodic television, even when its very good, is crafted as a series of short stories' (Simon, 2003). As a result, The Wire struggles to form its storyline the way ordinary humans struggle to form their own narratives. The drama presents stories made up of at first seemingly unrelated moments, rife with dead-ends and false leads, and the ever-present threat of the sheer pointlessness of any given endeavour. Contingency ricochets through the character's 
lives like a random bullet connecting with a state witness and setting in train an electoral revolution. Ultimately, the characters in The Wire shoulder the same work as the audience-to piece together meaning and sense from events that are sometimes causally connected, and at other times utterly contingent. They, like the audience, see the meaning of what they do as a live question demanding an answer-an answer that is not presented to them, and so one that must be built in a painstaking and piecemeal fashion, with no full idea of where the journey is leading and what exactly the story will come to mean. Yet even amidst the gunfire, confusion and the institutional oppression, The Wire's characters do glean a sense of meaning and direction-and so did its audience. And perhaps we may take some heart from the thought that if we can find narrative and meaning in Baltimore, and with it the nascent stirrings of virtue, then we can find it anywhere. ${ }^{1}$

\footnotetext{
${ }^{1}$ This paper benefited greatly from comments on a previous draft provided by two anonymous reviewers for REIO.
} 


\section{References}

Aristotle. (2002). Nicomachean ethics (J. Sachs, Trans.). Newbury, MA: Focus Publishing/R. Pullins.

Beadle, R., \& Knight, K. (2012). Virtue and Meaningful Work. Business Ethics Quarterly, 22(2), 433450.

Beadle, R., \& Moore, G. (2006). MacIntyre on Virtue and Organization. Organization Studies, 27(3), 323-340.

Breakey, H. (2014) Dividing to Conquer: Employing the Separation of Powers to Structure Institutional Inter-Relations. Research in Ethical Issues in Organizations 11.

Buchanan, A., \& Keohane, R. O. (2006). The Legitimacy of Global Governance Institutions. Ethics and International Affairs, 20(4), 405-437.

Chaddha, A., \& Wilson, W. J. (2010, 12 September, 2010). Why we're teaching 'The Wire' at Harvard, Opinion, The Washington Post. Retrieved from http://www.washingtonpost.com/wpdyn/content/article/2010/09/10/AR2010091002676.html

Crowther, P. (2002). Narrative and Self-Consciousness: A Basis for Virtue Ethics. Journal of Value Inquiry, 36(4), 435-443.

Fagan, T. (2013). All in the game. In D. Bzdak, J. Crosby \& S. Vannatta (Eds.), The Wire and Philosophy (pp. 13-29). Chicago: Open Court.

Hobbes, T. (1651/2008). Leviathan (J. Gaskin, Trans.). New York: Oxford University Press.

Human Rights Watch. 'Colombia: Criminal Groups Terrorize Neighborhoods, Displace Thousands.' $20^{\text {th }}$ March, 2014. http://www.hrw.org/news/2014/03/20/colombia-disappearances-plaguemajor-port.

Locke, J. (1690/1947). Two Treatises of Government. New York: Hafner.

Maclntyre, A. (1981). After virtue: a study in moral theory. London: Duckworth.

MacIntyre, A. (1994). A partial response to my critics. In J. Horton \& S. Mendus (Eds.), After Maclntyre (pp. 283-304). Cambridge: Polity. 
MacIntyre, A., \& Dunne, J. (2002). Alasdair MacIntyre on Education: In dialogue with Joseph Dunne. Journal of Philosophy of Education, 36(1), 1-19.

Montesquieu. (1748/1989). The Spirit of the Laws. New York: Cambridge University Press.

Moore, G., \& Beadle, R. (2006). In Search of Organizational Virtue in Business: Agents, Goods, Practices, Institutions and Environments. Organization Studies, 27(3), 369-389.

Rudd, A. (2007). In Defence of Narrative. European Journal of Philosophy, 17(1), 60-75.

Sachs, J. (2002). Three little words: Habit, mean, noble Nicomachean ethics (pp. xi-xxv). Newbury, MA: Focus Publishing/R. Pullins.

Sampford, C. (1988). The Disorder of Law. Oxford: Basil Blackwell.

Sampford, C., Smith, R., \& Brown, A. J. (2005). From Greek Temple to Bird's Nest: Towards A Theory of Coherence and Mutual Accountability for National Integrity Systems. Australian Journal of Public Administration, 64(2), 96-108.

Schneewind, J. B. (1982). Virtue, Narrative, And Community: MacIntyre And Morality. Philosophy, 79(11), 653-663.

Simon, D. (2003). David Simon Answers Fans' Questions. Retrieved from HBO Interviews website: http://web.archive.org/web/20031204070427/http://www.hbo.com/thewire/interviews/in dex.html

Simon, D. (2008). A final thank you to The Wire fans. Retrieved from http://www.hbo.com/thewire\#/the-wire/inside/interviews/article/finale-letter-from-davidsimon.html/eNrjcmbO0CzLTEnNd8xLzKksyUx2zs8rSa0oUc-PSYEJBSSmpol5qYy5zMXsjGyMXlyMrJJJ5aW5BfkJFbalhSVpgIAXbkXOA== 